\title{
Hubungan Pemberian Makanan Tambahan terhadap Perubahan Status Gizi Anak Balita Gizi Kurang di Kota Manado
}

\author{
${ }^{1}$ Kevin H. Hosang \\ ${ }^{2}$ Adrian Umboh \\ ${ }^{2}$ Hesti Lestari
}

\author{
${ }^{1}$ Kandidat Skripsi Fakultas Kedookteran Universitas Sam Ratulangi Manado \\ ${ }^{2}$ Bagian Ilmu Kesehatan Anak Fakultas Kedokteran Universitas Sam Ratulangi Manado \\ Email: kevinhosang15@gmail.com
}

\begin{abstract}
Toddler is one of the nutritional vulnerable population groups that easily suffer from health problems and malnutrition. In this age group, children are in growth and development cycle that requires nutrients in larger amounts than any other age groups. To overcome the problem of malnutrition in this age group, they should be supported with supplementary food. Pemberian makanan tambahan (PMT) is a program of intervention to infants suffering from malnutrition with a goal to improve the nutritional status as well as the nutritional needs of children to achieve the nutritional status and condition of good nutrition in accordance with the children's age. PMT for children aged 0-59 months is as an addition and not as a substitute of main daily meals. This study was aimed to determine the relationship of supplementary feeding to changes in the nutritional status of children under 5 years with malnutrition at health centers in Manado. This was an analytical retrospective study. Subjects were 70 children under 5 years with malnutrition fed with rice, biscuits, green beans, and milk for 90 days. The results showed that there was a very significant relationship between PMT and the changes in nutritional status of children under 5 years with malnutrition at health centers in Manado.
\end{abstract}

Keywords: feeding (PMT), toddler, child nutritional status

\begin{abstract}
Abstrak: Balita merupakan salah satu golongan penduduk rentan gizi yang paling mudah menderita gangguan kesehatan dan kekurangan gizi. Kelompok usia tersebut berada pada suatu siklus pertumbuhan atau perkembangan yang memerlukan zat-zat gizi dalam jumlah yang lebih besar dari kelompok umur yang lain. Untuk mengatasi masalah gizi pada kelompok usia tersebut perlu diselenggarakan pemberian makanan tambahan (PMT). PMT merupakan program intervensi terhadap balita yang menderita kurang gizi yang bertujuan untuk meningkatkan status gizi anak dan mencukupi kebutuhan zat gizi anak sehingga tercapainya status gizi dan kondisi gizi yang baik sesuai dengan usia anak tersebut. PMT bagi anak usia 059 bulan sebagai tambahan, bukan sebagai pengganti makanan utama sehari-hari. Penelitian ini bertujuan untuk mengetahui hubungan pemberian makanan tambahan terhadap perubahan status gizi anak balita gizi kurang di Puskesmas-puskesmas di Kota Manado. Jenis penelitian ialah analitik retrospektif. Subjek penelitian ialah 70 anak balita gizi kurang yang mendapatkan PMT berupa beras, biskuit, kacang hijau, dan susu selama 90 hari. Hasil penelitian menunjukkan bahwa PMT berpengaruh sangat bermakna terhadap perubahan status gizi anak balita gizi kurang di puskesmas-puskesmas Kota Manado.
\end{abstract}

Kata kunci: PM), balita, status gizi, balita gizi kurang

Masa lima tahun pertama kehidupan anak, merupakan masa golden age. Pada masa tersebut pertumbuhan fisik anak merupakan hal yang sangat penting karena sekitar $90 \%$ 
sel-sel otak anak akan tumbuh dan berkembang. ${ }^{1}$ Jika masa ini terabaikan, maka akan menjadi masalah kesehatan yang serius bagi balita tersebut, baik pada masa ini maupun di masa depan. ${ }^{2}$ Di Indonesia tujuan pembangunan utama dimulai dari peningkatan Sumber Daya Manusia (SDM) yang dilakukan secara berkelanjutan. Peningkatan SDM dimulai dari pemenuhan kebutuhan dasar manusia dan perhatian utama diberikan sejak masa tumbuh kembang anak dimulai sejak pembuahan sampai dewasa muda., Masalah gizi yang terjadi pada balita disebabkan oleh dua faktor yaitu faktor langsung dan tidak langsung. Faktor langsung ialah makanan anak dan penyakit infeksi yang mungkin diderita oleh anak tersebut, sedangkan faktor tidak langsung ialah ketahanan pangan keluarga, pola pengasuhan anak serta pelayanan kesehatan dan juga kesehatan lingkungan. ${ }^{5}$ Dalam menjalani kehidupannya seorang anak masih sangat tergantung kepada orang tuanya (ibu), sehingga pendidikan seorang ibu akan memengaruhi status gizi anaknya. Anak sehat dan dinyatakan bergizi baik, jika berat badan anak bertambah sesuai dengan bertambahnya umur. $^{6}$ Untuk mengatasi kekurangan gizi yang terjadi pada kelompok usia balita gizi kurang perlu diselenggarakan pemberian makanan tambahan (PMT). ${ }^{7}$ Pemberian makanan tambahan merupakan program intervensi terhadap balita yang menderita kurang gizi dimana tujuannya ialah untuk meningkatkan status gizi anak serta untuk mencukupi kebutuhan zat gizi anak sehinggga tercapainya status gizi dan kondisi gizi yang baik sesuai dengan usia anak tersebut. ${ }^{8}$ PMT bagi anak usia 6-59 bulan sebagai tambahan, bukan sebagai pengganti makanan utama sehari-hari. PMT dimaksud berbasis bahan makanan lokal dengan menu khas daerah yang disesuaikan dengan kondisi setempat.

Penelitian ini bertujuan untuk mengetahui hubungan pemberian makanan tambahan terhadap perubahan status gizi anak balita gizi kurang di Puskesmaspuskesmas di Kota Manado.

\section{METODE PENELITIAN}

Jenis penelitian yang dipakai ialah analisis retrospektif. Populasi penelitian ialah semua balita gizi kurang yang mendapatkan program PMT, di puskesmaspuskesmas Kota Manado. Sampel penelitian ialah balita menderita gizi kurang yang telah selesai diberikan program PMT. Populasi balita tersebut sekaligus dijadikan sampel penelitian ini dan karena jumlah populasi hanya sedikit maka tidak digunakan teknik sampling pada penelitian ini.

Jenis data ialah data sekunder yang berasal dari rekam medik anak, untuk melihat terapi dan pengobatan yang telah diberikan dan hasil pengisian lembar kuesioner. Analisis data univariat digunakan untuk menggambarkan karakteristik jenis kelamin, usia, pekerjaan orang tua, status gizi balita menurut klarifikasi Depkes RI setelah mendapat PMT, status gizi balita berdasarkan $\mathrm{BB} / \mathrm{TB}$ setelah mendapatkan PMT, dan riwayat penyakit. Analisis data menggunakan SPSS 22.0 dengan Uji Mc Nemar untuk mengetahui hubungan pemberian makanan tambahan terhadap status gizi anak balita gizi kurang. Asumsi penelitian menggunakan tingkat kesalahan $5 \%$.

\section{HASIL PENELITIAN}

Selama Tahun 2015 Program Pemberian Makanan Tambahan (PMT) dilakukan di 12 di Kota Manado yaitu Puskesmas Kombos, Puskesmas wawonasa, Puskesmas Tuminting, Puskesmas Bailang, Puskesmas Tongkaina, Puskesmas Bunaken, Puskesmas Bengkol Puskesmas Tikala Baru, Puskesmas Wenang, Puskesmas Ranomut, Puskesmas Teling atas dan Puskesmas Minanga. Data dalam penelitian ini diambil dari catatan medis dari pasien, yang merupakan Balita Gizi Kurang yang telah mendapatkan Pemberian Makanan Tambahan (PMT).

Sampel yang digunakan dalam penelitian ini berjumlah 70 orang. Sampel ini diambil dari catatan medis tahun 2015. Penelitian berlangsung dari bulan Oktober 2015 sampai Januari 2016. Penyajian hasil- 
hasil penelitian dalam bentuk tabel distribusi frekuensi mengenai karakteristik yang diamati.

Dari hasil penelitian didapatkan 36 sampel penelitian berjenis kelamin laki-laki $(51,4 \%)$ sedangkan sisanya 34 sampel berjenis kelamin perempuan $(48,6 \%)$ (Tabel 1).

Usia yang paling sering menderita gizi kurang ialah 0-24 bulan sebanyak 36 anak yang merupakan usia termuda dalam sampel penelitian. Usia tertua berada di usia 45-59 bulan sebanyak 6 anak. Pada usia 25-36 bulan terdapat 13 anak $(18,6 \%)$ dan pada 37-48 bulan 15 anak $(21,4 \%)$.

Karakteristik sampel berdasarkan pekerjaan orang tua ialah sebagai berikut: mayoritas pekerjaan orang tua ialah buruh/tukang sebanyak 17 orang (24,3\%), supir 14 orang $(20 \%)$, dan pedagang sebanyak 14 orang (20\%). Jenis mata pencarian yang paling sedikit ialah nelayan 9 orang $(12,9 \%)$, swasta 8 orang $(11,45)$, dan ibu rumah tangga 8 orang $(11,4 \%)$.

Berdasarkan klarifikasi status gizi menurut berat badan per tinggi badan setelah mendapat PMT, 56 orang $(80 \%)$ berstatus gizi baik (normal), sedangkan 14 orang $(20 \%)$ berstatus gizi buruk.

Berdasarkan riwayat penyakit didapatkan yang tertinggi ialah sampel tanpa riwayat penyakit berjumlah 25 anak $(35,7 \%)$, riwayat DBD berjumlah 18 anak $(25,7 \%)$, riwayat diare berjumlah 11 anak $(15,7 \%)$, dan sisanya asma 7 anak (10\%), tipus 5 anak $(7,2 \%)$, dan batuk pilek 4 anak $(5,7 \%)$.

\section{BAHASAN}

Dari 16 Puskesmas yang tersebar dikota Manado, yang diteliti hanya pada 12 Puskesmas yang melaksanakan program PMT pada Tahun 2015. Dari hasil penelitian diperoleh jumlah sampel sebanyak 70 anak Balita Gizi kurang dimana dari jumlah sampel yang didapatkan berjenis kelamin laki-laki berjumlah $36(51,4 \%)$ dan perempuan berjumlah $34(48,6 \%)$. Balita yang paling sering mengalami gizi kurang (sebelum pemberian PMT) ialah balita usia 0-24
Bulan yang berjumlah 36 anak $(51,4 \%)$.

Masalah gizi pada usia ini sesuia dengan penelitian yang dilakukan Turnip (2008) yang menyatakan bahwa usia 12-24 bulan berada pada masa perkembangan kritis terutama pada perkembangan otak, sehingga membutuhkan yang baik namun karena berbagai masalah mengakibatkan timbulnya masalah gizi pada anak. Pada 36 balita ini tersebar di kecamatan yang keadaan lingkungan tempat tinggal yang kurang higienis, juga dikarenakan rendahnya tingkat perekonomian dari masyarakat setempat serta berdekatan dengan daerah aliran sungai. Hal Ini mengakibatkan banyaknya virus dan Bakteri yang mengancam pertumbuhan dari anak Balita di Daerah tersebut. Ini juga berbanding lurus melihat dari data UNICEF (1999, dalam Asta Qauliyah, 2006) Bahwa sepertiga anak yang mengalami Gizi Kurang berada dibawah usia 3 tahun. $^{2}$ Proses tumbuh kembang anak bergantung juga dari pekerjaan yang dimiliki orang tua. Anak mendapat pemenuhan gizi yang semuanya dari hasil kerja orang tua. Semakin besar pendapatan orang tua, kebutuhan gizi anak akan terpenuhi. Dari 70 sampel balita anak gizi kurang, kebanyakan orang tuanya bekerja sebagai buruh/tukang 17 orang (24,3\%), supir 14 orang $(20 \%)$ dan pedagang 14 orang $(20 \%)$ serta nelayan 9 orang $(12,9 \%)$ yang bisa dikatakan pendapatan yang minim. Ada juga sebagai ibu rumah tangga 8 orang $(11,4 \%)$ dan kerja Swasta 8 orang $(11,4 \%)$.

Dalam penelitian mengenai tentang faktor yang berpengaruh terhadap status gizi balita yang menganalisis umur anak, jenis kelamin, usia orang tua, pekerjaan orang tua, tingkat pendidikan orang tua, jumlah anggota keluarga dan lamanya menyusui menunjukkan hasil bahwa pendapatan orang tua merupakan hal yang paling berpengaruh terhadap status gizi anak balita. ${ }^{9}$ Gizi balita dikatakan baik jika terdapat keseimbangan dan keserasian antara perkembangan fisik dan mental Balita dimana keadaan status gizi yang ditunjukkan balita di pengaruhi oleh konsumsi makanan yang diterima. ${ }^{2}$ 
Pemberian Makanan Tambahan kepada 70 anak balita yang dijadikan sampel dalam penelitian ini, semuanya diberikan PMT secara lengkap berupa beras, kacang ijo, susu dan biskuit, dimana hasilnya menunjukkan bahwa 56 orang (80\%) diantaranya telah mencapai hasil status gizi yang normal, sedangkan 14 (20\%) orang masih berstatus gizi kurang. Dari pengklasifikasian status gizi balita menurut Departemen Kesehatan Republik Indonesia, didapatkan hasil yang sama dengan klarifikasi status gizi balita menurut berat badan per tinggi badan. Hal ini menunjukkan, klarifikasi ini mempertimbangkan keaadan gizi pada masa lalu. Jadi, pengklasifikasian menurut $\mathrm{BB} / \mathrm{TB}$ yang disarankan oleh Departemen Kesehatan Republik Indonesia sangatlah cocok untuk diterapkan sebagai acuan dalam menentukan status gizi balita. Klarifikasi status gizi balita menurut berat badan per umur tidak dapat dijadikan sebagai acuan untuk penentuan, karena akan didapati lebih banyak balita dengan gizi kurang bahkan buruk. Oleh karena itu sesuai dengan acuan dari Departemen Kesehatan Republik Indonesia, acuan untuk pengukuran status gizi anak balita yang paling baik adalah berat badan menurut tinggi badan ditambah tanda klinis. ${ }^{3}$ Pada penelitian ini, didapatkan peningkatan status gizi setelah 90 hari PMT menjadi normal pada 56 orang $(80 \%)$. Pada penelitian yang pernah dilakukan dengan menggunakan susu skim 20 gram per hari selama 3 bulan. Hasil yang diperoleh ialah $80,8 \%$ balita gizi kurang menjadi balita gizi baik. ${ }^{9}$ Dalam sampel penelitian terdapat riwayat penyakit demam berdarah 18 balita $(25,7 \%)$, diare 11 balita $(15,7 \%)$, asma 7 balita (10\%), tipus 5 balita $(7,2 \%)$, batuk pilek 4 balita $(5,7 \%)$ dan tanpa riwayat penyakit 25 balita $(35,7 \%)$. Dalam penelitan, pengaruh buruk penyakit ialah nafsu makan yang berkurang sehingga dapat berpengaruh bagi balita dalam pemenuhan gizi. ${ }^{5}$ Dari 70 sampel anak gizi kurang yang telah mendapatkan PMT yang menjadi gizi baik 56 dan tetap gizi kurang 14, setelah diuji statistik dengan uji Mc Nemar yang membanding- kan sebelum dan sesudah PMT. Dalam pengujian didapatkan PMT berpengaruh bermakna terhadap perubahan status gizi balita.

Keterbatasan penelitian retrospektif dari data Rekam Medik sulit diterapkan untuk meneliti faktor-faktor yang menyebabkan anak balita gizi kurang setelah mendapatkan PMT tetap gizi kurang.

\section{SIMPULAN}

Berdasarkan hasil penelitian yang dilakukan dapat disimpulkan bahw terdapat hubungan yang sangat bermakna antara Pemberian Makanan Tambahan terhadap status gizi anak balita gizi kurang.

\section{SARAN}

Diharapkan Program Pemberian Makanan tambahan terus dilakukan menanggulangi masalah gizi kurang untuk mengejar nilai normal dari anak-anak gizi kurang. Sebaiknya diadakan penyuluhan akan pentingnya pemberian makanan empat sehat lima sempurna. Untuk kedepannya, diharapkan dilakukan penelitian yang mengidentifikasi faktor-faktor terjadinya gizi kurang di Kota Manado. Usia yang sering menderita gizi kurang pada penelitian ini oalah kurang dari 2 tahun (0-24 bulan), maka diperlukan perhatian khusus pada golongan umur tersebut untuk mencegah gizi kurang

\section{DAFTAR PUSTAKA}

1. Barness LA, Curran JS. Nutrisi. Edisi Nelson Ilmu Kesehatan Anak: Behrman, Kliegman, Arvin, 2000; p. 23-5

2. Arisman. Gizi dalam Daur Kehidupan. Jakarta: EGC, 2007; p. 14-5.

3. Notoatmodjo S. Ilmu Kesehatan Masyarakat Jakarta. Jakarta: Rineka Cipta,1996; p. 95-135.

4. Soekirman. Ilmu Gizi dan Aplikasinya. Jakarta: Direktorat Jenderal Pendidikan Tinggi Departemen Pendidikan Nasional, 2000; p. 1-2.

5. Putuhena. Hubungan antara pengetahuan gizi ibu dengan status gizi anak sekolah Taman Kanak-Kanak di Kecamatan Salaman Kabupaten 
Magelang Propinsi Jawa Tengah. Yogyakarta: Program Pasca Sarjana UGM, 1998; p. 50-2.

6. Riset kesehatan dasar. Laporan Nasional 2007. Badan Penelitian dan pengembangan Kesehatan Departemen Kesehatan RI. Jakarta, 2008; p. 23-5.

7. Departemen Kesehatan RI. Standar Antropometri Penilaian Status Gizi Anak. Direktorat Bina Gizi. Keputusan Menkes RI. No.1995/
Menkes/SK/XII/. Jakarta, 2010; p. $12-4$.

8. Kementrian Perencanaan pembangunan Nasional/Badan Perencanaan Pembangunan Nasional. Tentang Rancangan Pembangunan Jangka Menengah Nasional 2010-2014. Jakarta, 2013; p. 34-6.

9. Hatriyanti Y, Triyanti. Penilaian status gizi. In: Gizi dan Kesehatan Masyarakat. Jakarta: Raja Grafindo Persada, 2007; p. 261-9. 